\title{
Plant responses under environmental stress conditions
}

\begin{abstract}
Considering increasing world population plants cultivation expanded in many poor areas. One of the most popular stress in soils is nutrient element depression. Moreover salinity and drought stress nowadays increased in the world. In order to improve plants tolerance to these conditions it necessary to realize plant mechanism under abiotic and biotic stresses. Plant tolerance to these stresses is dependent to their genetics, environmental situation and the combination of these two elements. This report gives an overview of the recent literature on the plants resistance limitation, physiological mechanism and symptoms of nutrient elements, salinity, drought and biotic stresses. The review will conclude by identifying several prospects for future researches aiming to improve the product resistance to the stress conditions.
\end{abstract}

Volume 2 Issue 6 - 2015

\author{
Mohammad Pessarakli,' Maryam Haghighi, ${ }^{2}$ \\ Atena Sheibanirad ${ }^{2}$ \\ 'The University of Arizona, USA \\ ${ }^{2}$ Department of Horticulture, Isfahan University of Technology, \\ Iran
}

Correspondence: Mohammad Pessarakli, Department of Plant Sciences, The University of Arizona, USA,

Email pessarak@email.arizona.edu

Received: June 15, 2015 | Published: November 27, 2015

\section{Introduction}

There are 16 essential nutrient elements [carbon (C), hydrogen $(\mathrm{H})$, and oxygen $(\mathrm{O})$ that plants uptake them from the air and water, nitrogen $(\mathrm{N})$, phosphorus $(\mathrm{P})$, potassium $(\mathrm{K})$, calcium $(\mathrm{Ca})$, magnesium $(\mathrm{Mg})$, sulfur $(\mathrm{S})$, iron $(\mathrm{Fe})$, zinc $(\mathrm{Zn})$, manganese $(\mathrm{Mn})$, copper $(\mathrm{Cu})$, molybdenum (Mo), boron (B), chlorine ( $\mathrm{Cl}$ ) that plant uptake them from soil] that are constituent of plant tissue complex structure. Soil plant nutritionist also consider cobalt (Co) as a plant essential nutrient element, however, due to very minute amount of its content in plants, its deficiency has not been reported in the literature. Nutrient elements usually are uptaken as ions from the root environment.

Plants' ability to uptake the nutrient elements is related to the elements quantity and distribution in soils. Some elements such as nitrogen, phosphorus and potassium are accumulated in plant tissue with higher concentrations than that in the environment. ${ }^{1}$

Although, toxic elements such as lead $(\mathrm{Pb})$ aluminum (AL), and some micronutrients such as $\mathrm{Cu}$ in plant tissues are kept lower than that in the external medium. ${ }^{2,3}$ The many facts of plant responses to abiotic stresses may include morphological and cytological changes, alternation in metabolic pathways and transcriptional regulation of genes. ${ }^{4}$

Soil is a multiphasic system with different nutrient solution concentrations and just the small fraction of these elements are dissolved in water and plant is able to uptake them. Plant nutrient absorption ability is influenced by soil physical and chemical characteristics such as structure, texture, water content, $\mathrm{pH}$, fertility level and nutrient content. Nutrient elements are naturally absorbed in soil optimum $\mathrm{pH}$ of 6-7.5, but under sub-optimal conditions, higher or lower than this optimum $\mathrm{pH}$, can affect nutrient availability status. For example, in sodic (alkaline) soils, phosphorus, iron and molybdenum deficiency are usually observed. Also, in acid soils, plants suffer from $\mathrm{P}$ deficiency, although, toxic amount of aluminum is found under this condition. ${ }^{4}$ Root exudate compounds such as sugars, organic acids, secondary metabolites and enzymatic compositions increase plant nutrient uptake ability under various stress condition..$^{5,6}$

\section{Plant responses under mineral nutrient deficiency stress}

Under nutrient deficiency conditions, some secondary metabolite compounds are produced in plants. Phenolic compound is one of these compounds that could lead to diagnose plants' nutrient deficiency disorder complications. Macronutrients such as nitrogen, phosphorous, potassium, and sulfur cause more phenolic compound production. ${ }^{7,8}$ Visual disorders like red or purple color leaves happen because of anthocyanin accumulation. ${ }^{9}$

\section{Plant responses under macronutrients deficiency}

Plant responses under nitrogen deficiency: Nitrogen is one of the most prevalent elements and also quantitatively is the most important growth limiting factor. Nitrogen deprivation cause a vast range of physiological and morphological changes in plants. ${ }^{10}$ Also, according to Zhang et al., ${ }^{10}$ the biggest absorbable source of nitrogen for plants was nitrate $\left(\mathrm{NO}_{3}^{-}\right)$. In open hydroponic systems after a period of time, $\mathrm{NO}_{3}^{-}$level decreased. ${ }^{11}$ In order to compensate this $\mathrm{N}$ source deprivation, organic and inorganic sources of $\mathrm{N}$ can be used. ${ }^{11}$ Haghighi et al., ${ }^{12}$ indicated that by replacing inorganic $\mathrm{N}$ sources with humic and glutamic acid as an organic source of $\mathrm{N}$ with 25 and $50 \%$ portion of nitrate concentration no significant changes in lettuce shoot fresh and dry weights were observed. Although by decreasing the $\mathrm{NO}_{3}^{-}$level, nitrate reductase activity decreased. Glutamic acid enhanced $\mathrm{NO}_{3}^{-}$absorption and increased protein content more than humic acid. Furthermore, reactive oxygen scavenger enzymes like superoxide dismutase and peroxidase activity decreased under low nitrogen concentration, but humic acid improved these enzymes activity under nitrogen starvation condition. ${ }^{12}$

Plants under low levels of nitrogen developed an elevated root: shoot ratio with shortened lateral branches. ${ }^{13}$ Phenolic metabolism was observed in rice under $\mathrm{N}$-deficient conditions, where $\mathrm{p}$-coumaric acid and ferulic acid increased in top of the rice plant. ${ }^{14}$ Under low nitrogen availability, leaf area, chlorophyll content, photosynthesis rate, and biomass production in sorghum significantly decreased. ${ }^{14} \mathrm{At}$ the beginning of nitrogen deficiency, the older leaves show chlorosis 
when compared to the younger leaves because of the high mobility of nitrogen through phloem. Nitrogen deficiency induces the chloroplast disintegration and loss of chlorophyll. Necrosis occurs at later stages and if nitrogen deficiency continues, it ultimately results in stunted growth and plant death. ${ }^{15}$

Plant responses under phosphorus deficiency: Phosphorus is the second important nutrient required by plants. It is an essential component of nucleic acids, phosphorylated sugars, lipids and proteins which control all life processes. Phosphorus forms high energy phosphate bonds with adenine, guanine and uridine which act as carriers of energy for many biological reactions. Plants with high growth rate require a large amount of available phosphorus which is often not found in many soils. Therefore, in an agriculture system, it is usually necessary to add $\mathrm{P}$ fertilizer to the soils. ${ }^{16}$

The requirement of phosphorus for optimal growth is in the range of 0.3 to $0.5 \%$ of the plant dry matter. The toxicity may occur if the tissue concentration is more than $1 \%$ in the dry matter. ${ }^{17}$ Inorganic form of phosphorus is usually available for plant roots in soil and the phosphorus organic structure is generally phytic acid and found in plant seeds. ${ }^{18-20}$ Tropical and subtropical zones and also arid region soils are usually poor in $\mathrm{P}$ content. This is mainly, because at the low and the high $\mathrm{pH}$ of these soils, respectively, $\mathrm{P}$ makes complex phosphate compounds with $\mathrm{Fe}$ and other micronutrients as well as with $\mathrm{Ca}$ and $\mathrm{Mg}$ (Iron phosphate, calcium phosphate, and magnesium phosphate). Plants have two major mechanisms to increase phosphorus efficiency:

Normal $\mathbf{P}$ usage and enhanced $\mathbf{P}$ uptake: Plant growth rate is reduced and phosphorus is remobilized. ${ }^{21}$ In optimize case, phosphate and organic acid production are increased, root structure is modified and by producing more root hair, root surface area is increased. ${ }^{22}$ Since the phosphate availability is usually low in the soils, the plants have developed special adaptations to acquire the same with the help of multiple high affinity transporters. ${ }^{23,24}$ Vance et al ${ }^{25}$ found that plant growth is limited because of the inaccessible and unavailable form of $\mathrm{P}$ in the soil.

In enhance case, positive correlation between the amounts of low soluble P compound and root organic acid were observed in Brassica napus and Lupin albus, more organic acid was released under P deficiency. ${ }^{26,27}$ Citrate is the most phosphorus solubilizing compound. ${ }^{28}$ By transferring citrate synthesize gens, plants will be able to uptake more $\mathrm{P}$ under deficiency conditions. ${ }^{29}$ Also Arbuscular mycorrhizae (AM fungi) promote the plant growth by improving supply of phosphorus in the soil..$^{30}$ The type of mycorrhiza formed depends on the phosphorus $(\mathrm{P})$ content of the medium in different culture conditions. These authors observed an endomycorrhiza, together with ectomycorrhiza in the same root, in a P-poor medium and only ectomycorrhiza in a P rich medium. ${ }^{31}$ Mycorrhizas could effectively substitute for the root hairs in P uptake. ${ }^{32}$

\section{Plant responses under potassium deficiency}

Potassium plays a pivotal role in plant growth and development. Plants usually do not suffer from excess of potassium and magnesium concentrations in the soil, but the excess rate of $\mathrm{Mg}$ application caused chlorotic and necrotic symptoms in cucumber leaves. ${ }^{33,34}$ Although, their main effect is a competition between cations $\mathrm{Ca} 2+, \mathrm{Mg} 2+$, and $\mathrm{K}+$ uptake under salinity stress. ${ }^{35}$ Under salinity stress condition, potassium absorption decreased in tomato and cucumber. ${ }^{36}$ Potassium deficiency reduces growth, shortens inter nodes followed by bushy appearance, chlorosis and necrosis. The symptoms first appear on older leaves. It has been reported that the $\mathrm{K}+$ deficient plants are susceptible to lodging and drought..$^{37}$

\section{Plant responses under calcium deficiency}

In tomato plants, by reducing calcium availability, chlorophyll content diminished to $50 \%{ }^{38}$ In leaves which were exposed to $\mathrm{Ca}$ deficiency stress, less early photosynthesis products were produced and less respiratory compounds were found outside of the chloroplast. ${ }^{38}$ Limitation in early photosynthesis products transportation was reported due to calcium deprivation in plants. ${ }^{38}$ Under low calcium availability in coffee plants, less protein was produced. Furthermore, a significant correlation between Ca concentration and photosynthetic parameters were observed in coffee plants. ${ }^{39}$

Under calcium deficiency, less root and shoot branches were produced, this growth reduction was due to limitation in cell division and also inhabitation in carbohydrate translocation among the plant cells as well as other divalent cations movement related to the $\mathrm{Ca}$ concentration. Under Ca deficiency stress, potato plant produced less protein-N, RNA and DNA, whereas soluble nitrogen content of the plant significantly increased. ${ }^{40}$

Under calcium deprivation condition, photosynthesis and growth rate significantly reduced and under continues $\mathrm{Ca}$ deficiency, translocation of photosynthesis compounds from source to sink were limited. ${ }^{41}$

\section{Plant responses under magnesium deficiency}

Magnesium is an essential element for every living organism, especially plants. The $\mathrm{Mg}$ content of foliage part of the higher plants was reported $0.2 \%$ of the dry weight. ${ }^{42} \mathrm{Mg}$ has a pivotal role in ATPase, RNA polymerase, protein kinase and other enzymes' functions. ${ }^{43-45}$ Also $\mathrm{Mg}$ is one the most important parts of chlorophyll structure ${ }^{46}$ and essential for photosynthesis. Under early stage of Mg deprivation, sugar accumulation in source leaves was observed before reduction of photosynthesis and chlorophyll biosynthesis. ${ }^{47,48}$

A typical $\mathrm{Mg}$ deficiency symptom is leaf vines chlorosis. Development of chlorosis requires preceding degradation of chlorophyll, since $\mathrm{Mg}$ acts as the central atom in the chlorophyll molecule. As Mg is strongly bound to this molecule, chlorosis appears to be a late response to $\mathrm{Mg}$ deficiency. In plants well supplied with $\mathrm{Mg}$ only about $20 \%$ of the total $\mathrm{Mg}$ is bound to chlorophyll, whereas the remaining about $80 \%$ is present in more mobile forms. ${ }^{49}$ Kobayashi et al., ${ }^{50}$ reported that transpiration alleviation occurred before sugar accumulation and chlorosis in $\mathrm{Mg}$ deficient leaves.

In acid soils, Al limits plant growth. Magnesium application improved sorghum tolerance mechanism in acid soils and increased its grain yield. ${ }^{51}$ Under Al toxicity stress, plant roots are damaged and less nutrient elements are absorbed. Under this condition, by $\mathrm{Mg}$ supplement root surface area increased and plant growth improved. ${ }^{52}$ Under magnesium deficiency, older needles in six years old Picea abies seedlings showed tip burn and their chlorophyll content was reduced, while young needles remained green and had stable chlorophyll content. Carboxylation is a process which has a great role in ribulose-1, 5-bisphosfate carboxylase enzyme activity and this process was impaired under $\mathrm{Mg}$ deficiency thereby photosynthesis rate was reduced. ${ }^{53}$

\section{Plant responses under sulfur deficiency}

Sulfur limitation is one the most important inhibitors of plant 
growth in Eastern Europe. ${ }^{54}$ Sulfur deficiency symptoms were not easily diagnosed in cereal production under field condition. It normally had no visual symptoms, but total crop yield decreased. The deficiency is usually determined with plant tissue analysis. ${ }^{54} \mathrm{~A}$ relationship between the critical value of glutathione and wheat yield was reported by Zhao et al..$^{55}$ Glutathione concentration increased in wheat leaves by applying foliage sulfate concentration, while the nitrate and amid concentrations decreased. Schnug et al. ${ }^{56}$ reported that oilseed rape developed the most distinctive expression of symptoms of any crop deficient in S. The symptoms are very specific and thus are a reliable guide towards $\mathrm{S}$ deficiency.

There was no difference in the symptomatology of S deficiency in high and low glucosinolate containing oilseed rape varieties. ${ }^{56} \mathrm{As} \mathrm{S}$ is fairly immobile within the plant ${ }^{57}$ symptoms always show up in the youngest leaves. Contrary, when the plants are still small, symptoms can cover the entire plant. Deficiency symptoms in young foliar tissue of oilseed rape began to appear when the total $\mathrm{S}$ concentrations dropped below $2 \mathrm{mg} \mathrm{g}-1$ and $3.5 \mathrm{mg} \mathrm{g}-1 \mathrm{~S}$ in high glucosinolate and low glucosinolate containing cultivar soil seed rape, respectively. ${ }^{58}$ Leaves starving from $\mathrm{S}$ begin to develop chlorosis. It has been reported that the chlorosis started from the leaf's edge and spread over intercostal area, but left the zones along the veins always green..$^{59}$ Although, high value of anthocyanin in oilseed maybe one of the $\mathrm{S}$ starvation symptoms and chlorosis caused by $\mathrm{S}$ deficiency, it never turns into necrosis. $^{56,60}$

\section{Plant responses under micronutrients deficiency}

Micro nutrient include iron, zinc, copper, molybdenum, manganese, boron and chlorine. These elements involved in plant enzyme and other compound structure. Absence of these elements reduces plant growth and even may stop some plant function and decrease photosynthesis efficiency.

\section{Plant responses under iron deficiency}

Chlorosis of young leaves is the main symptom of iron deficiency. Low $\mathrm{Fe}$ availability is one the most important limitation for crop production in the world. Naturally iron has the insoluble form oxyhydrate with low bioavailability in the earth crust. High value of bicarbonate in the root medium decreases Fe mobility for plants. ${ }^{61}$ Iron uptake rate was correlated with leaves and shoots iron needs compare to their internal $\mathrm{Fe}$ concentration..$^{62}$ Plant response to iron deficiency is to increase the reduction of ferric iron $(\mathrm{Fe}+3)$ to its ferrous form $(\mathrm{Fe}+2)$. Mugineic acid is a kind of peptide which known as phytosidrophores compound. ${ }^{63}$ One method to increase this substrate change in the soil is added mugineic acid to the rhizosphere. ${ }^{64}$ Furthermore, transferring mugineic acid biosynthesis genes improved iron uptake system. ${ }^{64,65}$

\section{Plant Responses under zinc deficiency}

Zinc $(\mathrm{Zn})$ is predominant in the transcriptional and translational machinery, where it has been estimated to account for 12 to $50 \%$ of all cellular Zn content of plants. ${ }^{66}$ Zinc deficiency occurs on millions of hectares of the world's cereal-growing soils, especially in the arid and semi-arid regions ${ }^{67,68}$ Critical $\mathrm{Zn}$ deficiency concentrations in leaves are given as 15 to $20 \mu \mathrm{g}$ g-1 dry biomass by Marschner et al. ${ }^{69}$ According to Marschner et al. ${ }^{69} \mathrm{Zinc}$ is toxic at concentrations above 100 and $300 \mu \mathrm{g} g-1$ for various plants. These values are only general guidelines.

Different species and even varieties of the same species differ in their $\mathrm{Zn}$ efficiency, for example their ability to maintain growth and yield under $\mathrm{Zn}$-limiting conditions. ${ }^{70}$ Responses to $\mathrm{Zn}$ fertilizer vary considerably and are influenced by soil available Zn. For example, in studies with ten barley cultivars and two $\mathrm{Zn}$ fertilization levels ( 0 and $23 \mathrm{~kg} \mathrm{Zn}$ ha-1) on various soils, Yilmaz et al., ${ }^{71}$ observed increases in grain yield ranging from $15 \%$ (DTPA extractable $\mathrm{Zn}$ in soil $=0.15 \mathrm{mg}$ $\mathrm{kg}-1$ ) to $202 \%$ (DTPA extractable $\mathrm{Zn}=0.11 \mathrm{mg} \mathrm{kg}-1$ ). In comparisons among selected bean and wheat cultivars, respectively, $\mathrm{Zn}$ efficiency was found to reside primarily in the ability of the leaves to maintain expression and activity of $\mathrm{Zn}$-requiring enzymes at low total leaf $\mathrm{Zn}$ concentrations. ${ }^{72,73}$

The rates and affinities of high and low-affinity $\mathrm{Zn}$ uptake systems in the root were similar ( 0.6 to $2 \mathrm{nM}$ and 2 to $5 \mu \mathrm{M} \mathrm{Zn2+}$, respectively) in two wheat varieties irrespective of differing in $\mathrm{Zn}$ efficiencies. ${ }^{74}$ Visible Zn deficiency symptoms range from initial early senescence of the old leaves or slight yellowing of the younger leaves to the formation of the yellow chlorotic or even necrotic areas on the leaves. Severely Zn-deficient plants appear stunted and exhibit reduced elongation and tip growth. ${ }^{69}$

Another study reported the grain yield of barley increased up to $60 \%$ after foliar application of $\mathrm{Zn}$ on six soils with ETDA-extractable $\mathrm{Zn}$ of $0.6-2.0 \mathrm{mg} \mathrm{kg}-1$ soil. $^{75}$ In wheat, the stem and the growing zones of the plant, i.e., the root tips and the meristematic region at the base of the leaves are the predominant sinks for $65 \mathrm{Zn} 2+$ applied to the cut surface of a leaf blade. ${ }^{76}$ The published data are consistent with a high requirement for $\mathrm{Zn}$ in dividing and elongating plant cells. ${ }^{69,77}$ Biochemically, $100 \mu \mathrm{g}$ g-1 and $70 \mu \mathrm{g}$ g-1 $\mathrm{Zn}$ in dry biomass are necessary to prevent the disintegration of $80 \mathrm{~S}$ ribosomes in rice meristems and tobacco cells, respectively. At lower $\mathrm{Zn}$ concentrations, biomass production is decreased.

\section{Plant responses under manganese deficiency}

Manganese (Mn) is another important microelement, particularly in legumes for nitrogen fixation. Mn addition to the soil caused an increase in soybean yield and also by increasing Mn level the leaves Mn content increased. ${ }^{78}$ Under Mn limitation condition, wheat leaves became mottled by continuing this situation, chlorophyll content was reduced and plant appearance turned yellow. ${ }^{79}$ In the poor manganese content soils, pelleted sugar beet seed with manganese oxide showed deficiency symptoms later than those pelleted with manganese sulphate, also $\mathrm{MnO}_{2}$ is an economically inexpensive compound that can be used to prevent Mo deficiency symptoms. ${ }^{80}$

Mn deficiency symptoms become visible when growth rate and yield are considerably decreased, Mn deficiency usually appears as diffuse interveinal chlorosis on the young expanded leaf blades, therefore, it is associated with $\mathrm{Mg}$ deficiency, but these are characteristically located on the old leaves, with Mn deficiency, necrotic spots or marginal necrosis may also develop. ${ }^{81}$ In dicotyledons the chlorosis develops first on the distal portions of the affected leaf blades, whereas in cereals, the leaf bases are first affected. ${ }^{82}$ The appearance of Mn deficiency symptoms on the young leaves results from immobility of Mn from the old leaves when Mn supply is limited. ${ }^{82}$

\section{Plant responses under copper deficiency}

Copper is involved in several metabolic processes and is an essential trace element for higher plants. ${ }^{83}$ The most common copper protein in higher plants is plastocyanin, which is localized in the thylakoid lumen of chloroplasts and is involved in photosynthetic electron 
transport. ${ }^{84}$ Another major copper protein is copper/zinc superoxide dismutase, which has a role in the scavenging of reactive oxygen species. ${ }^{85}$ Young leaves margin necrosis, lateral shoot death, unshaped leaf margin, bleeding in main node stem and low lignification value in vessels are the visual symptoms of copper deficiency stress. ${ }^{86}$

In Eucalyptus maculate seedlings the $\mathrm{Cu}$ critical value in shoot were $1.5 \mu \mathrm{g}$ g-1dry weights, the external $\mathrm{Cu}$ supplement did not affect the $\mathrm{Cu}$ concentration in plants. ${ }^{86}$ Under low copper availability the cytochrome oxidase activity was reduced, this enzyme has a role in plant root nodule cells recovery under low oxygen stress for nitrogen fixation.$^{87}$ In acid soils, $\mathrm{Cu}$ deficiency symptoms are usually observed. In a study by adding $\mathrm{Cu}$ supplement, more nitrogen concentration was found in the $\mathrm{Cu}$ supplemented Pinus radiata leaves than the control plants. $^{88}$

\section{Plant responses under molybdenum deficiency}

Molybdenum is one of the essential micronutrient elements for plant growth and is a composition of nitrate reductase and nitrogenase enzymes. Nitrogen fixation in all plants needs Mo element. Fabaceae family had a greater need to Mo, especially when extra nitrogen fertilizer was used, Mo needs were higher. ${ }^{89}$ Legume Mo rich seeds have to be sown in acid Mo deficient soils. In Mo deficient soils, nitrogen fixation and shoot and nodule dry weights decreased in Phaseolus vulgarisand the seed Mo content was reduced to 83$85 \% .{ }^{89}$ Under molybdenum deficiency condition with Azotobacter application more amount of Mo and also N2 absorbed bay plants and make them to have better yield. ${ }^{90}$

\section{Plant responses under boron deficiency}

Base on Grahm et al., ${ }^{91}$ reports micronutrient deficiencies such as iron, born, zinc, and manganese impaired soybean growth and development. Probably, the best way of increasing plant resistance to nutrient deficiency is to improve plant gens. The interaction of B and Zn deficiency had a significant effect on callus weight. ${ }^{91}$ The resistance ability was found in the cellular stage, and it could be transferred to the next plant growth stage. ${ }^{91}$ Under B deficiency condition, one of the rapid visible responses is the inhibition or cessation of the roots and shoots elongations. ${ }^{92,93}$ Under borne starvation condition, a morphological change is lateral bud growth limitation in some plants. ${ }^{94}$ There is a hypothesis indicates that the primary role of boron is in lignin biosynthesis and in conjunction with auxin (indole-3acetic acid, IAA) in xylem differentiation, the reason related to the phenolic compound accumulation under B starvation condition ${ }^{95}$ and also a reduction happens in lignin biosynthesis of boron-deficient tissue. ${ }^{96}$

\section{Plant responses under chlorine deficiency}

Chlorine is one of the essential micronutrient elements that its deficiency is rarely seen in plants. Chlorine deficiency symptoms in some cereal products like barley and corn were resulted in less cluster formation and less yield. ${ }^{97}$ Chloride is mainly involved in the photolysis of water by photosystem II. Chloride may either act as a bridging ligand for stabilization of the oxidized state of manganese $\mathrm{e}^{98}$ or as a structural moiety of the extrinsic protein. ${ }^{99}$ Chlorine plays an important role in the stomatal movement. ${ }^{100}$ Under chlorine starvation, leaf area was reduced and plant biomass production decreased. ${ }^{101}$ The most common $\mathrm{Cl}$ - deficiency symptoms were reported as leaves wilting, chlorotic mottling, bronzing, and tissue necrosis. ${ }^{99}$

\section{Drought stress}

Drought stress is one the most common stresses for plants which can happen when the water supply to the roots is limited or when the transpiration rate is too high. These two conditions usually coincide with arid and semi-arid climates. Low water availability limited photosynthesis activity due to imbalance between light capture and its utilization so that oxidative stress happened. ${ }^{102}$ Drought stress induced a significant reduction in photosynthesis, which is dependent on photosynthesizing tissue and photosynthetic pigments. ${ }^{103,104}$ During stresses, active solute accumulation (i.e., soluble carbohydrates, proteins, and free amino acids) is claimed to be an effective stress tolerance mechanism. ${ }^{105}$

Changes in the photochemistry of the chloroplasts in the leaves of drought-stressed plants resulted in dissipation of excess light energy, thus, generated reactive oxygen species. ${ }^{106}$ Reactive oxygen species will be destroyed by some biological mechanisms, including anti-oxidant activity (i.e., superoxide dismutase, catalase, ascorbate peroxidase, peroxidase, glutathione reductase, monodehydroascorbate reductase, dehydroascorbate reductase antioxidants) and nonenzymatic activity (i.e., flavones, anthocyanins, carotenoids, and ascorbic acid antioxidants). ${ }^{107}$

In a study, Ahmadi et al. ${ }^{108}$ reported that maize was grown under different nitrogen levels exposed to the drought stress, mild drought stress increased the Catalase (CAT) activity, however, severe stress decreased it. Moreover, they [108] observed that nitrogen fertilizer significantly increased CAT activity when applied at highest level. Also, drought stress significantly increased the Superoxide Dismutase (SOD) activity. ${ }^{108}$ At the mild water stress level, Peroxidase (POD) activity met its peak level, however, at sever water stress its activity was suppressed and even fell below the control level. ${ }^{108}$

Nitrogen fertilizer significantly increased the POD activity. Also, nitrogen application significantly increased proline concentration. Protein concentration increased by water stress and the highest concentration of protein was occurred at mild water stress level, however, there was not statistically any significant difference between mild and sever water stress levels. ${ }^{108}$ In a drought tolerate sesame cultivar (Isfahan4) seed yield, leaf carotenoid content and root proline were higher than non-resistance varieties. In addition, increasing these kinds of metabolites helped the plant to overcome drought stress condition. ${ }^{109}$ In two bean cultivars under drought stress condition, height, number of leaves, leaf area, number of pods, pod dry matter and total plant weights of both cultivars were significantly decreased. ${ }^{110}$ Drought stress also causes an increase in proline content, although protein content may reduce. ${ }^{105}$

\section{Salinity stress}

Under salinity stress mineral ion uptake maybe decreased. Ion transportation rate under salt stress condition is reduced and this phenomenon is happened because of low root absorption rate or low xylem sap efficiency. Low nutrient supplement under stress condition caused a reduction in cell division or cell expansion or extra $\mathrm{NaCl}$ leaked into inter cellular spaces. ${ }^{111}$ Under osmotic stress conditions, plants are forced to escape from the salt accumulated area and make roots to be adapted to the saline condition. Under long period of salinity stress, roots available water is decreased and lower amounts of nutrient elements are absorbed by the roots. 
One of the most important adjustment mechanisms is to absorb more, low nutrient element concentration in the soil, but less $\mathrm{NaCl}$ uptake. ${ }^{112,113}$ Sonneveld et al., ${ }^{113}$ reported that by increasing $\mathrm{NaCl}$ in the root zone medium, nutrient uptake increased and higher amounts of nutrients were accumulated in the plant tissues.

Under salinity stress condition, calcium absorption in the root medium is decreased maybe because of an osmotic disorder, but it causes plants to suffer from nutrient deficiency. Calcium regulation under saline conditions was one the most important plant changes and caused some physiological disorders such as blossom end rot in sweet pepper $^{114}$ in eggplant ${ }^{115}$ and in tomato. ${ }^{116,117}$

Furthermore calcium deficiency caused tip burn disorder in lettuce ${ }^{118,119}$ and Chinese cabbage, celery blackheart ${ }^{120}$ leaves necrosis in cucumber. ${ }^{33,34,121}$ It was reported that based on plant species and salt concentration, an interaction between salt and phosphorus content may happen. ${ }^{122-124}$ In some plant species under saline conditions, $\mathrm{P}$ toxicity symptoms were observed. ${ }^{125}$ These symptoms were related to the substrate solution in the root zone environment. Also phosphorus suppressed $\mathrm{Ca}$ uptake by plants, and under low $\mathrm{P}$ content, $\mathrm{Ca}$ absorption decreased, and aggravated blossom end rot in tomatoes was observed. ${ }^{126}$ Moreover, under high $\mathrm{P}$ concentrations, Ca uptake increased. ${ }^{127}$

Reduction in nutrient uptake and metabolism and protein synthesis under salt stress conditions has been reported by several investigators. ${ }^{128-133}$ Salinity increased NO3- and SO42-concentrations in the root zone. High SO42- concentration reduced calcium absorption capacity. ${ }^{134}$ Specific effects of these ions were not found under conditions that the $\mathrm{NO}_{3}^{-}$supply was sufficient. ${ }^{135}$ Replacement of $\mathrm{NO}_{3}{ }^{-}$by $\mathrm{Cl}-$ in rock wool grown tomatoes strongly aggravates the Ca uptake. ${ }^{136}$ It is not yet clear what phenomenon is responsible for the increased uptake of $\mathrm{Ca}$, the high $\mathrm{Cl}-$, the low $\mathrm{NO}_{3}^{-}$, or a combination of both changed Ca concentrations. ${ }^{137}$

Sweet pepper had a strong resistance against the uptake of Na under saline conditions, in this process, particularly the pith cells played a decisive role in retarding the movement of $\mathrm{Na}$ from the shoots. ${ }^{138}$ Water and ion transportation among the soil-plant-atmosphere continuum are negatively suppressed by salt accumulation in the soil. ${ }^{139}$ Salinity stress suppresses plant growth in several ways. Parida et al., ${ }^{140}$ believe that leaf area reduction is the first effect of salt stress on plant growth. Salt stress reduced $\mathrm{CO}_{2}$ concentration around the stomata, diminished cell membrane permeability for $\mathrm{CO}_{2}$, reduced the sink capacity of the leaves, and in turn, reduced photosynthesis activity. ${ }^{139,140}$ Under salinity condition, fresh and dry weights, root volume, stem diameter, sub stomatal $\mathrm{CO}_{2}$, photosynthetic rate, mesophyll conductance, and photosynthetic water use efficiency all reduced, but electrolyte leakage increased by increasing salinity levels in cherry tomatoes. ${ }^{141}$

Silicon ( $\mathrm{Si}$ ) is the second most abundant mineral element in the soil and the ability of Si to ameliorate the negative effect of sodium chloride $(\mathrm{NaCl})$ on plant growth rate is well documented. ${ }^{139}$ By application of Si fresh and dry weights, root volume, and chlorophyll concentration increased furthermore, photosynthesis rate, mesophyll conductance and plant water use efficiency were enhanced under salinity stress condition. ${ }^{141}$ Pessarakli et al., ${ }^{142}$ and Pessarakli \& Touchane ${ }^{143}$ examined bermudagrass ${ }^{143,144} \mathrm{cv}$. Tifway 419 and seashore paspalum (Paspalum vaginatum Swartz), cv. Sea Isle 2000 under salinity stress conditions. They found that under low salinity level, root length increased but high level of salinity decreased it. They also reported that under long term exposure to salt stress, higher reduction in shoot and root fresh and dry weights were observed.

In other studies shoot and root lengths and shoot fresh and dry weights decreased linearly with increased salinity levels in various rye grass (Lolium perenne L.) cultivars. ${ }^{145,146}$ In all the examined cultivars, root length was more severely affected than the shoot length. ${ }^{145,146}$ In twelve clones of salt grass which were exposed to salinity stress, no significant changes in nitrogen uptake was observed, but the root nitrogen concentration was higher than that of the shoot. ${ }^{147}$ In some wheat cultivars, under long time exposure to salinity, some anti-oxidant enzymes such as peroxidase and superoxide dismutase increased, conversely proline content decreased. ${ }^{148}$ In this study, by applying foliage gibberllic acid wheat growth was enhanced. ${ }^{148}$

In a comparison between wheat and maize cultivars under salinity stress condition, higher amounts of proline, peroxidase activity, and protein content in wheat cultivars were observed. ${ }^{149}$ Higher amounts of $\mathrm{K}+$ and $\mathrm{K}+/ \mathrm{Na}+$ ratios in wheat compared to maize resulted in better ion homeostasis in wheat that caused this species to have a higher salinity tolerance than maize. ${ }^{149}$ In another research on spring durum wheat relative water content, potassium and total chlorophyll content and membrane stability index reduced under soil salinity conditions but proline and total soluble sugar increased. ${ }^{150}$

In some cases, by using calcium in salinity stress studies, the toxicity effects of salt stress have been reduced. For example, in three foliage plants, African millet, tall wheat grass, and perennial ryegrass, supplemental calcium reduced the adverse effects of salinity. ${ }^{151}$ Distichlis spicata L. is a halophytic plant species which was fertilized with $15 \mathrm{~N}$ under salinity stress conditions. The plant did not show any significant differences in $\mathrm{N}$ content in shoots under salinity stress conditions compared with the control plants.

However, root length and root dry weight as well as nitrogen uptake by this halophytic plant species increased by increased salt levels. This grass species could be recommended for restoration and revegetation of the arid lands. ${ }^{152}$ Different types of salts can induce different plant reactions. Under high $\mathrm{EC}$ values resulted from $\mathrm{NaCl}$ and $\mathrm{Na}_{2} \mathrm{SO}_{4}$ salts, all the growth parameters of African millet, tall wheat grass, and perennial ryegrass reduced. However, under high $\mathrm{EC}$ values which were resulted by adding $\mathrm{KCl}$ and $\mathrm{K}_{2} \mathrm{SO}_{4}$ salts, these growth parameters were not significantly different.

In addition, sensitivity to sulfate and chloride was equal when sodium concentrations in shoots were equal. ${ }^{153}$ In two barley cultivars, Hordeum murinum and Hordeum vulgar, phosphorous as an element had a role in this plant species salt resistance, $P$ promoted other mineral ions accumulation in the cells and inhibited sodium accumulation. Also phosphorous addition increased total yield of these barley cultivars under $\mathrm{KCl}$ and $\mathrm{K}_{2} \mathrm{SO}_{4}$ salts. ${ }^{154}$

Salt stress can result in the formation of Reactive Oxygen Species (ROS), such as superoxide, hydrogen peroxide, and hydroxyl radicals. These ROS damage proteins, membrane lipids, and nucleic acids. ${ }^{155-157}$ Plants have developed enzymatic systems for scavenging ROS, to prevent oxidative injury. Catalase (CAT), Peroxidase (POX), and Ascorbate Peroxidase (APX) play a role in the metabolism of ROS. Antioxidant enzymes have been shown to contribute in resistance to damage induced by salt stress. ${ }^{154,158,159}$ Malondialdehyde, a decomposition product of polyunsaturated fatty acids of membranes, has been shown to be accumulated under salt 
stress. ${ }^{154,160}$ Alterations of APX, POX, and CAT activities under salt stress have been investigated in several plant species. Increase in POX and APX activities in cowpea (Vigna unguiculata (L.) Walp ${ }^{161}$ and CAT activity in tobacco (Nicotiana tabacum L.) ${ }^{162}$ and decrease in CAT activity in cowpea ${ }^{161}$ have been reported under salt-stress conditions. Polyunsaturated fatty acids of plant membranes are decomposed to Malondialdehyde (MDA) under salt stress.

Therefore, the rate of lipid peroxidation in terms of MDA may be used as a biochemical indicator to evaluate the tolerance of species and cultivars within species to oxidative stress and the sensitivity of plants to salt stress as suggested by Jain et al., ${ }^{163}$ Wang et al., ${ }^{164,165}$ reported that MDA content in the roots and leaves of alfalfa seedlings increased with exception of the roots of the tolerant cultivar (Xinmu No.1). The MDA content was higher in the sensitive cultivar (Northstar) than the tolerant one under all salt-stress conditions, suggesting an enhanced capacity for protection from oxidative damage by the tolerant cultivar

Similarly, Babakhani et al., ${ }^{166}$ reported that MDA content of alfalfa cultivars' seedlings increased with increased salinity levels. Babakhani et al., ${ }^{166}$ showed that POX activity of alfalfa cultivars increased with increased salt level, however, salt-induced POX activity was significantly higher in the salt tolerant than in the sensitive cultivar. Sekmen et al., ${ }^{167}$ showed that APX activities in Plant ago were depending on the species and salinity level. The APX activity in the leaves of hoary plantain and sea plantain increased and did not change under 100 and $200 \mathrm{mM} \mathrm{NaCl}$. Catalase is an oxidoreductase enzyme and breaks down $\mathrm{H}_{2} \mathrm{O}_{2}$ to oxygen and water. ${ }^{168}$ This enzyme does not require a reducing power and has a high reaction rate, but a low affinity for $\mathrm{H}_{2} \mathrm{O}_{2}$, thereby only removing the high concentrations of $\mathrm{H}_{2} \mathrm{O}_{2}{ }^{169}$ Noreen \& Ashraf 2009 reported a reduction in CAT activity of pea (Pisum sativum L.) under salt stress.

\section{Temperature stress}

Suboptimal temperature limits plant growth and function. High temperatures restricts cool-season plant growth during summer in many regions of the world. The optimum temperature for $\mathrm{C} 3$ plants' growth is reported $15-25^{\circ} \mathrm{C}$ by several scientists. ${ }^{170-172}$ During the warm season high temperature limited photosynthesis and carbohydrate accumulation, increased cell membrane damages caused protein folding and even cell death in $\mathrm{C} 3$ plants. ${ }^{172}$ The same damages have been reported in warm-season plants, $\mathrm{C} 4$ plant species, during the winter. Also, the $\mathrm{C} 4$ species absorbed less water and needed to modify themselves to be able to uptake nutrient elements with low solubility. ${ }^{173}$

During the summer, reducing nitrogen fertilizer helps the $\mathrm{C} 3$ plants to decrease their growth rate and overcome the high temperature stress condition. Under the high temperature stress condition, if extra amount of nutrients were available in the root zone, the plants would grow faster and consume all their storage carbohydrates, so that they do not have any storage compound to overcome winter low temperature stresses. ${ }^{172,174,175}$ Nevertheless, plants need their basic required amount of nutrient elements to continue their metabolisms. ${ }^{176}$ Applying calcium to the nutrient solution increased plant heat stress tolerance. ${ }^{177-180}$ Under low temperature stress condition, Rosa $\times$ hybrida $c v$. Grand Gala absorbed higher amount of NO3 and this phenomenon happened because of increased in nitrate reductase activity. ${ }^{173}$

Seed germination is the first step of plant regeneration. Temperature has been reported one the most important climatic factors which limited plant growth and distribution around the world. ${ }^{56,171,172}$ Black cumin is one of the indigenous plants of Iran which has specific medical usage. Its basal germination temperature ranges 16.9 to $22.14^{\circ} \mathrm{C}$ the highest temperature that germination was observed in this species was $31.52^{\circ} \mathrm{C} .{ }^{181}$

Cardinal temperatures for the endemic plants in each ecotype were different in order to propagate these plants to other regions the producers have to consider cardinal germination and growth temperatures. ${ }^{181}$ Temperature is one of the most important abiotic factors which was reported to suppress the germination processes. ${ }^{182,183}$ Also, cardinal temperature has been reported to induce seed dormancy and prevent seed germination. ${ }^{184}$ In Guayule (Parthenium argentatum A. Gray) the highest germination rate was observed at $20^{\circ} \mathrm{C}$ and the lowest seed germination was found at $30-40^{\circ} \mathrm{C} .^{62}$

\section{Plant responses to biotic stress}

Biotic stresses include weeds, insects, diseases, etc. which cause damages to plant growth and morphology. Nutrient supplement under these conditions can improve plant recovery. ${ }^{185-187}$ Weeds are usually appeared and grown under poor soil conditions and by applying enough nutrient elements to the root environment; it is possible to prevent weeds development and their side effects on plant growth. By improving nutrient use efficiency plants vigor is enhanced and they will be able to overcome weed growth. Nevertheless, under this condition, both weed and the main plant nutrient use efficiency is increased. ${ }^{188,189}$

Moreover, plant disease has a complex relation with mineral elements. For example extra nitrogen content with high humidity level is suitable for pathogen like phytium and phytophtera growth and development on plants. ${ }^{185,186}$ In turfgrasses by adding $\mathrm{Mn}$ and $\mathrm{Si}$ elements to the nutrient solution, the grasses overcome disease easier and faster. ${ }^{190}$ Plants with sufficient nutrient supplies recover more and faster than the nutrient deficient plants from the insect's injury. In a research by using $\mathrm{Al}$ and $\mathrm{Si}$ for turfgrass growth medium, these elements protected the plants from the insect injuries and also helped them to make an unattractive compound for the insects diet. ${ }^{190}$

\section{Conclusion}

Throughout this review, we have discussed the effects of biotic and abiotic stress on physiological mechanism of plants. This is an aim to enhance plant performance under unfavorable growth conditions in which plants have to deal with suboptimal and/or supra optimal temperatures, water stress nutrient elements stress and biotic stress. The full understanding of the effects of different stress will help producers to increase their crop resistance and have higher yield over the world producers and breeders attempted to increase nutrient element efficiency and it would be possible with realizing nutrient elements absorption and movement throw the plant cells and their effects on physiological process. Eventually we could say that with an efficient nutrient element management decreasing physiological and morphological damages under stress condition become a possible aim.

\section{Acknowledgements}

None.

\section{Conflict of interest}

The author declares no conflict of interest. 


\section{References}

1. Steward FC, Sutcliffe JF. Plants in relation to in organic salt. Plant Physiology. A Treatise. Volume II; 1959.

2. Barber DA. Dual isotherm for absorption of ions by plant tissue. New Phytologist. 1972;71:255-262.

3. Watanabe T. Disruption and chemical speciation of aluminum in the Al accumulator plant, Melastoma malabathricum. L Plant and Soil. 1998;201:165-173.

4. Meyerowitz EM, Somerville CR. Arabidopsis. New York, USA: Cold Spring Harbor Press; 1994.

5. Bais HP, Weir TL, Perry LG, et al. The role of root exudates in rizosphere interactions with plants and other organisms. Annual Review of Plant Biology. 2006;57:233-66.

6. Ryan P. Function and mechanism of organic anion exudation from plant roots. Annual Review of Plant Physiology and Plant Molecular Biology. 2001;52:527-560.

7. Gershenzon J. Changes in levels of plant secondary metabolites under water and nutrient stress. Advances in Photochemistry. 1983;18:273320 .

8. Mc Clue JW. The physiology of phenolic compounds in plants. Recent Advances Photochemistry. 1977;12:525-556.

9. Hewitt EJ. The essential nutrient element:requirement and interaction in plants. Plant Physiology. 1963;3:137-360.

10. Zhang H, Jennings A, Barlow PW, et al. Dual pathways for regulation of root branching by nitrate. Proceeding of National Academy of Science. 1999;96:6529-6534.

11. Panuccio MR, Muscolo A, Nardi S. Effect of humic substances on nitrogen uptake and assimilation in two species of Pinus. Journal of Plant Nutrition. 2001;24:693-704.

12. Haghighi M. The effect of humic and glutamic acids in nutrient solution on the $\mathrm{N}$ metabolism in lettuce. Journal of the Science of Food and Agriculture. 2012;92(15):3023-3028.

13. Scheible WR, Lauerer M, Schulze ED, et al. Accumulation of nitrate in the shoot acts as a signal to regulate shoot - root allocation in tobacco. Plant Journal. 1997;11:671-691.

14. Zhao D, Reddy KR, Kakani VG, et al. Nitrogen deficiency effects on plant growth, leaf photosynthesis, and hyperspectral reflectance properties of sorghum. European journal of agronomy. 2005;22:391-403.

15. Forde BG. Nitrate transporters in plants:structure, function and regulation. Biochimica et Biophysica Acta. 2000;1465:219-235.

16. Holfor ICR. Soil phosphorus:its measurement and its uptake by plants. Australian Journal of Soil Research. 1997;35:227-239

17. Toyota K, Koizumi N, Sato F. Transcriptional activation of Phosphoenol pyruvate carboxylase by Phosphorus deficiency in tobacco. J Exp Bot. 2003;54:961-969.

18. Schatman DP, Reid RJ, Ayling SL. Expression of the yeast FRE gens in transgenic Tabaco. Journal of Plant Physiology. 1998;118:51-58.

19. Baker AJ, Reeves M, Hajar RD, et al. Heavy metal accumulation and tolerance in British population of metallophyte Thlaspi carerulescens (Brassicaceae). New Physiologist. 1994;127:61-68.

20. Schat H, Llugany M, Viojs R, et al. The role of phytochelatiins in constitutive and adaptive heavy metal tolerance in hyper accumulator and non-hyper accumulator metallophyte. Journal of Experimental Botany. 2002;53:2381-2392
21. Uhde-Stone C, Gilbert G,Jhonson J, et al. Acclimation of white lupin to phosphate deficiency involves enhanced expression of gens related to organic acid metabolism. Plant and Soil. 2003;248:99-116.

22. Abel S, Ticconi CA, Delatorre CA. Phosphate sensing in higher plants. Physiologia Plantaruma. 2002;115:1-8.

23. Raghothama KG. Phosphate acquisition. Annu Rev Plant Physiol Plant Mol Biol. 1999;50:665-693.

24. Herrera Estrella L, Guevara Garcia A, Lopez Bucio J. Heavy metal adaption. London: Encyclopedia of Life Science Macmillan Publishers; 1999. p. 1-5.

25. Vance CP, Uhde Stone C, Allan DL. Phosphorus acquisition and use:critical adaptations by plants for securing a non-renewable resource. New Phytologist. 2003;157:423-447.

26. Hoffland E, Findenegg G, Nelemans JA. Solubilization of rock phosphate by rape. Local root exudation of organic acids as response to $\mathrm{P}$ starvation. Plant and Soil. 1989;113:161-165.

27. Dinkelar B, Romheld V, Marschner H. Citric acid extraction and precipitation of calcium citrate in rizhospher of white lupin (Lupinus albus L.). Plant Cell and Environment. 1989;12:285-292.

28. Staunton S, Leprince F. Effect of $\mathrm{pH}$ and some organic anions on solubility of soil phosphate:implication for P bioavaibility. European Journal of Soil Science. 1996;47:231-239.

29. Lopez Bucio J, Hernandez Abreu E, Sanchez Calderon L, et al. Phosphate availability alters architecture and cause in hormone sensitivity in the Arabidopsis root system. Plant Physiology. 2002;129:244-256.

30. Tinker PB, Jones MD, Durall DM. A functional comparison of ecto and endo mycorrhizae. In: "Mycorrhizae in Ecosystems". Read DJ, et al. editors. Welling ford, UK: CAB International; 1992. p. 303-310.

31. Fortas Z, Chevalier G. Effect of culture conditions on the mycorrhization of Helianthemum guttatum by three species of desert truffles of the genera Terfezia and Tirmania of Algeria. Can J Bot. 1992;70(12):24532460 .

32. Jakobsen I, Chen BD, Munkvold L, et al. A root hairless barley mutant depends on arbuscular mycorrhizal fungi for efficient phosphate acquisition. Plant Cell Environ. 2005;28:928-938.

33. Abed AH. Einfluss von Salzkonzentration und Konzentrationsänderung in der Nährlösung auf Assimilation und Transpiration von Gurkenpflanzen. Dissertation Technischen Universität Hannover; 1973. 117 p.

34. Sonneveld C, Voogt SJ. Effects of saline irrigation water on glasshouse cucumbers. Plant and Soil. 1978;49:595-606.

35. Sonneveld C. Specifieke zouteffecten bij chrysant. Proefstation voor Tuinbouw onder Glas Naaldwijk. Intern verslag; 1981. p. 8-18.

36. Besford RT. Effect of sodium in the nutrient medium on the incidence of potassium deficiency symptoms in tomato plants. Plant and Soil. 1978;50:427-432.

37. Lindhauer MG. Influence of $\mathrm{K}$ nutrition and drought on water relation and growth of sunflower (Helianthus annuus L.). Journal of Plant Nutrition and Soil Science. 1985;148:654-669.

38. Rangnekar P. Effect of calcium deficiency in the carbon metabolis$\mathrm{ms}$ in photosynthesis and respiration in tomato leaf. Plant and Soil. 1975;42:565-583.

39. Ramalho JC, Rebelo MC, Santos ME, et al. Effect of calcium deficiency on coffee Arabica nutrient changes and correlation of calcium levels with some photosynthetic parameters. Plant and Soil. 1995;179:87-96.

40. Singh OS, and Sharma VK. Alternation in growth and metabolism of potato plants by calcium deficiency. Plant and Soil. 1972;36:363-369. 
41. Rangnekar P. Effect of calcium deficiency on the translocation and utilization of C14-photosynthate in tomato plants. Plant and Soil. 1974;41:589-600.

42. Hawkesford M, Horst W, Kichey T, et al. Functions of Macronutrients In: Marschner's Mineral Nutrition of Higher Plants. 3rd ed. Londo: Academic Press; 2012. p. 135-189.

43. Maguire M, Cowan J. Magnesium chemistry and biochemistry. Biometals. 2002;15:203-210.

44. Dann CE, Wakeman CA, Sieling CL, et al. Structure and mechanism of a metal-sensing regulatory RNA. Cell. 2007;130:878-892.

45. Shaul O. Magnesium transport and function in plants:the tip of the iceberg. Biometals. 2002;15:309-323.

46. Cakmak I, Kirkby EA. Role of magnesium in carbon partitioning and alleviating photo oxidative damage. PhysiologyPlant. 2008;133:692704.

47. Hermans CGN, Johnson RJ, Strasser N, et al. Physiological characterization of magnesium deficiency in sugar beet:acclimation to low magnesium differentially affects photosystems I and II. Planta. 2004;220:344-355.

48. Hermans C, Verbruggen N. Physiological characterization of $\mathrm{Mg}$ deficiency in Arabidopsis thaliana. Journal of Experimental Botany. 2005;56:2153-2161.

49. Marschner H. Mineral nutrition of higher plants. Academic, Elsevier 3rd ed. 2012. 672 p

50. Kobayashi NI, Takayuki S, Iwata N, et al. Leaf senescence in rice due to magnesium deficiency mediated defect in transpiration rate before sugar accumulation and chlorosis. Physiologia Plantarum. 2013;148:490-501.

51. Tan K, Keltjens WG, Findengg GR. Acid soil damages in sorghum genotype:role of magnesium deficiency and root impairment. Plant and Soil. 1992;139:149-155.

52. Tan K,Keltjens WG, Findengg GR. Evaluating the contribution of magnesium deficiency in aluminum toxicity syndrome in twelve sorghum genotype. Plant and soil. 1993;149:255-261.

53. Jakobs BM. Seasonal development of the photosynthetic performance of Norway spruce Piceaabies L. under magnesium deficiency. Plant and Soil. 1995;169:255-261.

54. Whelpdale DM. Acid deposition, distribution and impact. Water Quality Bulletin.1983;8:72-80.

55. Zhao FJ, Hawkesford MJ, Warrilow AGS, et al. Response of two whea varieties to sulfur addition and diagnose of sulfur deficiency. Plant and Soil. 1996;181:317-327.

56. Schnug E. Bestimmung des Gesamtglucosinolatgehaltes in vegetativen Pflanzenteilen durch quantitative Analyse enzymatisch freisetzbaren Sulfates. Analytical and Bioanalytical Chemistry. 1988;330:50-55.

57. Cram WJ. Uptake and transport of sulfate. In:Sulfur nutrition and sulfur assimilation in higher plants. H Rennenberg (Ed.), The Netherlands: SPB Academic Publishing; 1990. p. 3-11.

58. Schnug E, Haneklaus S. Sulphur deficiency in Brassica napus - biochemistry, symptomatology, morphogenesis. Landbauforschung Volkenrode, FAL-Braunschweig, Sonderheft; 1994. 144 p.

59. Lobb WR, Reynolds DG. Further investigations in the use of sulphur in North Otago. New Zealand Journal of agriculture. 1956;92:17-25.

60. Horiguchi T. Effects of nitrogen, phosphorus and manganese deficiencies on the formation of anthocyanin and other phenolic compounds in plants. Soil Science and Plant Nutrition. 1989;60:226-232.
61. Grusak MA. Whole-root iron III reductase activity through the life cycle of iron grown Pisium sativum L. (Fabaceae). Relevance to the iron nutrition of developing seed Planta. 1995;197:111-117.

62. Sanchez PL, Chen MK, Pessarakli M, et al. Effects of temperature and salinity on germination of non-pelleted and pelleted guayule (Parthenium argentatum A. Gray) seeds. Industrial Cropsand Products. 2014;55:90-96.

63. Lombi E, Tearall KL, Howarths JR, et al. Influence of iron status on cadmium and zinc uptake by different ecotype of hyper accumulator Thlaspi carerulescens. Plant Physiology. 2002;128:1359-1367.

64. Mori S. Iron acquisition by plants. Current Opinion in Plant Biology. 1999;2:250-253.

65. Higuchi K, Suzuki K, Nakanishi H, et al. Cloning of nicotinamine synthase gens, novel gens involved in biosynthesis of phytosidrophers. Plant Physiology. 1999;119:471-480.

66. Finney L, O’Halloran TV. Transition metal speciation in the cell:insights from the chemistry of metal ion receptors. Science. 2003;300:931936.

67. Graham RD, Ascher 1S, Hynes SC. Selecting Zn-efficient cereal genotypes for soils of low zinc status. Plant and Soil. 1992;146:241-250.

68. Takkar PN, Walker CD. The distribution and correction of Zn deficiency. In: Robson AD editor. Zinc in Soils and Plants, Kluwer Academic Publishers; 1993. p. 151-166.

69. Marschner H. Mineral Nutrition of Higher Plants. 2nd ed. London, UK: Academic Press Ltd; 1995.

70. Graham RD, Rengel Z. Genotypic variation in zinc uptake and utilization by plants. In: Robson AD editor. Developments inPlant and Soil Sciences: Zinc in soils and plants. Netherlands: Kluwer Academic Publishers; 1993. p. 107-118.

71. Yilmaz A, Kalayci M, Ekiz H, et al. Tolerance of barley genotypes to Zn deficiency, Turkey; 1995.

72. Hacisalihoglu G, Hart JJ, Vallejos CE, et al. Zinc efficiency is correlated with enhanced expression and activity of zinc-requiring enzymes in wheat. Plant Physiology. 2003;131:595-602.

73. Hacisalihoglu G, Hart JJ, Vallejos CE, et al. The role of shoot-localized processes in the mechanism of $\mathrm{Zn}$ efficiency in common bean. Planta. 2004:218:704-711.

74. Hacisalihoglu G, Hart JJ, Kochian LV. High and low-affinity zinc transport systems and their possible role in zinc efficiency in bread wheat. Plant Physiology. 2001;125:456-463.

75. MacNaeidhe FS, Fleming GA. The effect of zinc and magnesium application on ear density, grain development, and grain yield of winter and spring barley (Hordeum vulgare L.) crops on some Irish soils. Dordrecht: Kluwer Academic Publishers.; 1990. p. 251-255.

76. Haslett BS, Reid RJ, Rengel Z. Zinc mobility in wheat:Uptake and distribution of zinc applied to leaves or roots. Annual Botany. 2001;87:379-386

77. Ma JF, Hiradate S, Nomoto K, et al. Internal detoxification mechanism of $\mathrm{Al}$ in Hydrogena. Identification of $\mathrm{Al}$ from the leaves. Plant Physiology. 1997;1113:1033-1039.

78. Bansal RL, Nayyar VK. Critical manganese deficiency level for soybean grown in Ustocherpts. Fertilizer research. 19900;25:153- 157.

79. Ferrari J, Sluijsmans CMJ. Mottling and magnesium deficiency in oats and their dependence on various factors. Plant and Soil. 1955;6:262299 
80. Farley RF, Draycott AP. Manganese deficiency in sugar beet and the incorporation of manganese in the coating of pelleted seed. Plant and Soil. 1978;49:71-83.

81. Wallace T. In The Diagnosis of Mineral Deficiencies in Plants by Visual Symptoms. A Color Atlas and Guide. IIM Stationery Office, London; 1961.

82. Robson AD, Snowball k. Nutrient deficiency and toxicity symptoms. In: Reuter DJ, editors. Plant Analysis. An Interpretation Manual. Australia: Inkata Press; 1986. p. 13-19.

83. Pilon M, Abdel-Ghany SE, Cohu CM, et al. Copper cofactor delivery in plant cells. Current Opinion in PlantBiology. 2006;9:256-263.

84. Weigel M, Varotto C, Finazzi G, et al. Plastocyanin is indispensable for photosynthetic electron flow in Arabidopsis thaliana. The Journal of Biological Chemistry. 2003;278:31286-31289.

85. Bowler C, Van Camp W, Van Montagu M, et al. Superoxide dismutase in plants. Critical Reviews in PlantSciences. 1994;13:199-218.

86. Dell B. Copper nutrition of Eucalyptus amculataHook. Seedlings:Requirement for growth, distribution of copper and the diagnosis of copper deficiency. Plant and Soil. 1994;181:181-187.

87. Cartwright B, Hallsworth EG. Effect of copper deficiency on root nodules of subterranean clover. Plant and Soil. 1970;33:685-698.

88. Turvey ND. Copper deficiency in Pinus radiata planted in a podzol in Victoria, Australia. Plant and Soil. 1984;77:73-86.

89. Brodrick AJ, Sakala MK, Giller KE. Molybdenum reserves of seed, growth and $\mathrm{N} 2$ fixation by Phaseolus vulgaris L. Biology and Fertility of soils. 1992;13:39-44.

90. Franco AA, Peres RR, Nery M. The use of Azotobacter paspali N2-ase (C2H2-reduction activity) to measure molybdenum deficiency in soils. Plant and soil. 1978;50:1-11.

91. Gharam MJ, Heavener DL, Nickell CD, et al. Response of soybean genotype to boron, zinc and manganese deficiency in tissue culture. Plant and Soil. 1993;150:307-310.

92. Bohnsack C, Wand Albel LS. Early effects of boron deficiency on indoleacetic acid oxidase levels of squash root tips. Plant Physiology. 1977;59:1047-1050.

93. Kouchi H. Rapid cessation of mitosis and elongation of root tip cells of Vida faha as affected by boron deficiency. Soil Science and Plant Nutrition. 1977;23:113-119.

94. Kramer U, Cotter-Howells JD, Charnock JM, et al. Free histidine as a metal chelator in plants that accumulate nickel. Nature. 1996;379:635638.

95. Troitskaya EA, Maevskaya AN, Temp GA. Hydroxyproline content in cell walls of plants with different boron requirements. Soviet Plant Physiology. 1975;22:854-857.

96. Skok J. The role of boron in the plant cell. In: Lamb CA, et al. editors. Trace Elements New York, USA: Academic Press; 1958. p. 227-243.

97. Johanson CM, Stout PR, Broyer TC, et al. Comparative chlorine requirements of different plant species. Plant and Soil. 1957;8:337-353.

98. Critchley C. The role of chloride in photosystem II. Biochimica et Biophysica Acta. 1985;11:33-46.

99. Coleman WJ, Govindjee, Gutowsky HS. The location of the chloride binding sites in the oxygen-evolving complex of spinach photosystem II. Biochimica et Biophysica Acta. 1987;894:453- 459

100. Raschke K, Hedrich R, Beckmann U, et al. Exploring biophysical and biochemical components of the osmotic motor that drives stomatal movement. Botanica Acta. 1988;101:283-294.
101. Terry N. Photosynthesis, growth and the role of chloride. Plant Physiology. 1977;60:69-75.

102. Foyer $\mathrm{CH}$, Noctor G. Oxygen processing in photosynthesis:regulation and signaling. New Phytology. 2000;146:359-388.

103. Dubey RS. Photosynthesis in plants under stressful conditions. In: Pessarakli M, et al. editors. Handbook of Photosynthesis. CRC Press; 2005. p. 717-718.

104. Raza SH, Athar HR, Ashraf M. Influence of exogenously applied glycinebetaine on photosynthetic capacity of differently adapted wheat cultivars under salt stress. Pakistan Journal of Botany. 2006;38:341351.

105. Jaleel CA, Kishore kumar P, Manivannan A, et al. Salt stress mitigation by calcium chloride in Phyllanthus amarus. Acta Botanica Croatica. 2008;67:53-62.

106. Peltzer D, Dreyer E, Polle A. Differential temperature dependencies of antioxidative enzymes in two contrasting species. Plant Physiology and Biochemistry. 2002;40:141-150

107. Johnson SM, Doherty SJ, Croy RRD. Biphasic superoxide generation in potato tubers:A self amplifying response to stress. Journal of Plant Physiology. 2003;13:1440-1449.

108. Ahmadi A, Emam Y, Pessarakli M. Biochemical changes in maize seedlings exposed to drought stress conditions at different nitrogen levels. Journal of Plant Nutrition. 2010;33:541-556.

109. Kadkhodaei A, Razmjoo J, Zahedi M, et al. Selecting sesame genotypes for drought tolerance based on some physiochemical traits. Agronomy Journal. 2013;106:111-118.

110. Emam Y, Shekoofa A, Salehi F, et al. Drought stress effects on two common bean cultivars with contrasting growth habits. Archives of Agronomy and Soil Science. 2011. p. 1-8.

111. Bernstein L. Effects of salinity and sodality on plant growth. Annual Review of Phytopathology. 1975;13:295-312.

112. Sonneveld C. Effects of salinity on substrate grown vegetables and ornamentals in greenhouse horticulture. Netherlands: Thesis Wageningen University; 2000. 151 p.

113. Sonneveld C, De Kreij C. Response of cucumber (Cucumis sativis L.) to an unequal distribution of salts in the root environment. Plant and Soil. 1999;209:47-56.

114. Sonneveld C, Van der Burg AMM. Sodium chloride salinity in fruit vegetable crops in soilless culture. Netherlands Journal of Agricultural Science. 1991;39:115-122.

115. Savvas D, Lenz F. Influence of salinity on the incidence of physiological disorder "internal fruit rot" in hydoponical-grown eggplants. Journal of Applied Botany. 1994;68:32-35.

116. Adams P, El-Gizawy AM. Effect of salinity and watering level on the calcium content of tomato. Acta Horticulture. 1986;190:253-259.

117. Adams P, Ho LC. Effects of environment on the uptake and distribution of calcium in tomato on the incidence of blossom-end rot. Plant and Soil. 1993;154:127-132.

118. Sonneveld C, Van Beusekom J. The effect of saline irrigation water on some vegetables; 1974.

119. Wiebe HJ. Untersuchungen über den Blattrandbrand bei Kopfsalat. Gartenbauwissenschaft. 1967;32:375-385.

120. Geraldson CM. Factors affecting calcium nutrition of celery, tomato and pepper. Soil Science Society American Proceeding. 1957;21:621625 . 
121. Shimida N. Excess injury of calcium and magnesium in the crops. Japan Agricultural Research. 1973;7:173-177.

122. Cerda A, Bingham FT, Hoffman GJ. Interactive effect of salinity and phosphorus on sesame. Soil Science Society of America Journal. 1977;41:915-918.

123. Cerda A, Bingham FT. Yield, mineral composition and salt tolerance of tomato and wheat as affected by $\mathrm{NaCl}$ and $\mathrm{P}$ nutrition. Agrochemical. $1978 ; 12: 140-149$

124. Maas EV, Nieman RH. Physiology of plant tolerance in salinity. In: Crop Tolerance to Suboptimal Land Conditions. USA: American Society of Agronomy Special Publication; 1978. p. 277-299.

125. Howell W, Bernhard RL. Phosphorus response of some soybean varieties. Crop Science. 1961;1:311-313.

126. De Kreij C. Interactive effects of air humidity, calcium and phosphate on blossom-end rot, leaf deformation, production and nutrient contents of tomato. Journal of Plant Nutrition. 1996;19:361-377.

127. Vaughan AKF. The relation between the concentration of boron in the reproductive. Voogt W, et al. editors. Hoge fosfaat concentraties hebben negative effect en. Groenten en Fruit. 1977;44(35):38-39.

128. Dubey RS, Srivastava RK, Pessarakli M. Physiological Mechanisms of Nitrogen; 2014.

129. Izadi MH, Rabbani J, Emam Y, et al. Effects of Salinity Stress on Physiological Performance of Various Wheat and Barley Cultivars. Journal of Plant Nutrition. 2014;37:520-531.

130. Nikbakht Ali, Mohammad Pessarakli. New approaches to turfgrass nutrition: humic substances and mycorrhizal inoculation. In: Handbook of Plant and Crop Physiology. 3rd ed. Revised and Expanded (M. Pessarakli, Ed.), CRC Press, Florida: Taylor \& Francis Publishing Group; 2014. p. 913-925.

131. Pessarakli M. Physiological Responses of Cotton (Gossypium hirsutum L.) To Salt Stress. 2014;9(11).

132. Ghanbari, Ali Akbar, Seyyed Hassan Mousavi, Mohammad Pessarakli. Accumulation of Reserve Compounds in Common Bean Seeds under Drought Stress. Journal of Plant Nutrition. 2015;38(4):609-623.

133. Lotfi, Ramin, Mohammad Pessarakli, Puriya Gharavi-Kouchebagh, et al. Physiological responses of Brassica napus to fulvic acid under wate stress:chlorophyll a fluorescence and antioxidant enzymes activity. The Crop Journal. 2015;3(5):434-439.

134. Bernstein L. Physiological basis of salt tolerance in plants. Genetic Control Diversity in Plants. Pakistan: Plenum Press; 1976. p. 283-290.

135. Nukaya AW, Hashimoto H. Effects of nitrate, chloride and sulfate ratios and concentration in the nutrient solution on yield, growth and mineral uptake characteristics of tomato plants grown in closed rock-wool system. Acta Horticulture. 2000;511:165-171.

136. Voogt W, Sonneveld C. Interactions between nitrate (NO3) and chloride $(\mathrm{Cl})$ in nutrient solutions for substrate grown tomato. Acta Horticulture. 2004;644:359-368.

137. Ma JF, Zhang SJ, Matsumoto H. Specific secretion citric acid induced by $\mathrm{Al}$ stress in Cassia tora L. Plant and Cell Physiology. 1997;38:1019-1025.

138. Blom-Zandstra M, Vogelzang SA, Veen BW. Sodium fluxes in sweet pepper exposed to varying sodium concentrations. Journal of Experimental Botany. 1998;49:1863-1868

139. Kafi M, Rahimi Z. Effect of salinity and silicon on root characteristics, growth, water status, proline content and ion accumulation of purslane (Portulaca oleracea L.).Soil Science and Plant Nutrition. 2011;57:341347.
140. Parida AK, Das AB. Salt tolerance and salinity effects on plants:a review. Ecotoxicology and Environmental Safety. 2005;60:324-349.

141. Haghighi M, Pessarakli M. Influence of silicon and nano-silicon on salinity tolerance of cherry tomatoes (Solanum lycopersicum L.) at early growth stage. Scientia Horticulturae. 2013;161:111-117.

142. Pessarakli Mohammad. Using Bermudagrass (Cynodon dactylon L.) In Urban desert landscaping and as a forage crop for sustainable agriculture in arid regions and combating desertification. International Journal of Water Resources and Arid Environments. 2015;4(1):8-14.

143. Pessarakli M, Touchane H. Growth responses of bermudagrass and seashore paspalum under various levels of sodium chloride stress. Journal of Food, Agriculture and Environment. 2006;4:84-87.

144. Pessarakli, Mohammad Hayat Touchane. Biological technique in combating desertification processes using a true halophytic plant. International Journal of Water Resources and Arid Environments. 2011;1(5):360-365.

145. Pessarakli M, Kopec DM. Screening various ryegrass cultivars for salt stress tolerance. Journal of Food, Agriculture and Environment 2009; 7:132-136.

146. Marcum Kenneth B, Mohammad Pessarakli. Relative Salinity Tolerance of 35 Lolium spp. Cultivars for Urban Landscape and Forage Use. In: Faisal K Taha, et al. editors. Developments in Soil Salinity Assessment and Reclamation: Innovative Thinking and Use of Marginal Soil and Water Resources in Irrigated Agriculture. (C) Springer Science \& Business Media Dordrecht 2013. Dubai, UAE: International Center for Bio-saline Agriculture; 2013. p. 397-403.

147. Pessarakli M, Harivandi MA, Kopec DM, et al. Growth Responses and Nitrogen Uptake by Saltgrass (Distichlis spicata L.), a Halophytic Plant Species, under Salt Stress, Using the $15 \mathrm{~N}$ Technique. International Journal of Agronomy; 2012. p. 1-9.

148. Aflaki Manjili F, Sedghi M, Pessarakli M. Effects of phytohormones on proline content and antioxidant enzymes of various wheat cultivars under salinity stress. Journal of Plant Nutrition. 2012;35:1098-1111.

149. Ahmadi A, Emam Y, Pessarakli M. Response of various cultivars of wheat and maize to salinity stress. Journal of Food, Agriculture and Environment. 2009;7:123-128.

150. Khosh Kholgh Sima NA, Askari H, Mirzaei H, et al. Genotype-dependent differential responses of three forage species to calcium supplement in saline conditions. Journal of Plant Nutrition. 2009;32:579 $-597$.

151. Khosh Kholgh Sima NA, Askari H, et al. Genotype-dependent differential responses of three forage species to calcium supplement in saline conditions. Journal of Plant Nutrition. 2009;32:579 - 597.

152. Pessarakli M, Kopec DM. Growth Responses and Nitrogen Uptake of Saltgrass (Distichlis spicata L.), a True Halophyte, under Salinity Stress Conditions using 15N Technique. Proceedings of the International Conference on Management of Soils and Ground Water Salinization in Arid Regions, Muscat. 2010;2:1-11.

153. Khosh Kholgh Sima NA, Ahmad ST, Pessarakli M. Comparative study of different salts (sodium chloride, sodium sulfate, potassium chloride, and potassium sulfate) on growth of forage species. Journal of Plant Nutrition. 2013;36:214-230

154. Khosh Kholgh Sima NA, Ahmad ST, Alitabar A, et al. Interactive effects of salinity and phosphorus nutrition on physiological responses of two barley species. Journal of Plant Nutrition. 2012;35:1411-1428.

155. Foyer $\mathrm{CH}$, Noctor $\mathrm{G}$. Oxidant and antioxidant signaling in plants:A reevaluation of the concept of oxidative stress in a physiological context. Plant Cell Environ. 2005;28:1056-1071. 
156. Sharma P, Jha AB, Dubey RS, et al. Reactive oxygen species (ROS) generation, hazards and defense mechanisms in plants under environmental (Abiotic and Biotic) Stress Conditions. In: M Pessarakli editor. Handbook of Plant and Crop Physiology. 3rd ed. Revised and Expanded, CRC Press, Florida: , Taylor \& Francis Group; 2014. p. 509-547.

157. Saed-Moucheshi, Armin, Avat Shekoofa, Mohammad Pessarakli. Reactive Oxygen Species (ROS) generation and detoxifying in plants. Journal of Plant Nutrition. 2014;37:1573-1585.

158. Bor M, Ozdemir F, Turkan I. The effect of salt stress on lipid peroxidation and antioxidants in leaves of sugar beet Beta vulgaris L. and wild beet Beta maritima L. Plant Sci. 2003;164:77-84.

159. Ashraf M, Harris PJC. Potential biochemical indicators of salinity tolerance in plants. Plant Sci. 2004;166 (1):3-16.

160. Gossett DR, Millhollon EP, Lucas MC. Antioxidant response to $\mathrm{NaCl}$ stress in salt-tolerant and salt-sensitive cultivars of cotton. Crop Sci. 1994;34:706-714.

161. Maia JM, Voigt EL, Macedo CE, et al. Salt induced changes in antioxidative enzyme activities in root tissues do not account for the differential salt tolerance of two cowpea cultivars. Braz J Plant Physiol. 2010;22:113-122.

162. Celik O, Cimen A. The effect of salt stress on antioxidative enzymes and proline content of two Turkish tobacco varieties. Turk J Biol. 2012;36:339-356.

163. Jain M, Mathur G, Koul S, et al. Ameliorative effects of proline on salt stress-induced lipid peroxidation in cell lines of groundnut (Arachis hypogea L.). Plant Cell Rep. 2001;20:463-468.

164. Wang WB, Kim YH, Lee HS, et al. Analysis of antioxidant enzyme activity during germination of alfalfa under salt and drought stresses. Plant Physiol Biochem. 2009;47:570-577.

165. Wang XS, Han JG. Changes of proline content, activity, and active isoforms of antioxidative enzymes in two alfalfa cultivars under salt stress. Agric Sci China. 2009;8:431-440.

166. Babakhani B, Khavari-Nejad RA, Hassan Sajedi R, et al. Biochemical responses of Alfalfa (Medicago sativa L.) cultivars subjected to $\mathrm{NaCl}$ salinity stress. Afr J Biotechnol. 2011;10:11433-11441.

167. Sekmen AH, Turkana I, Takiob S. Differential responses of antioxidative enzymes and lipid peroxidation to salt stress in salt-tolerant Plantago maritime and salt-sensitive Plantago media. Physiol Plant. 20007;131:399-411.

168. Smirnoff N. The role of active oxygen in response of plants to water deficit and desiccation. New Phytol. 1993;125:27-58.

169. Hongbo SL, Zongsuo, Mingan S. Changes of anti-oxidative enzymes and MDA content under soil water deficits among 10 wheat (Triticum aestivum L.) genotypes at maturation stage. Colloids Surf B Biointerfaces. 2005;45:7-13.

170. Beard JB. Turfgrass: Science and Culture. Prentice-Hall, Inc., Englewood Cliffs, NJ absorption and assimilation in plants under stressful conditions. In: M Pessarakli editor. Handbook of Plant and Crop Physiology. 3rd ed. Revised and Expanded, CRC Press, Florida: Taylor \& Francis Publishing Group; 1973. p. 453-485.

171. DiPaola JM. Syringing effects on the canopy temperatures of bentgrass greens. Agronomy Journal. 1984;76:951-953.

172. Fry JD, Huang B. Applied Turfgrass Science and Physiology. New Jersey, USA: John Wiley \& Sons Hoboken; 2004.
173. Calatayud A, Gorbe E, Roca D, et al. Effect of two nutrient solution temperatures on nitrate uptake, nitrate reductase activity, $\mathrm{NH} 4+$ concentration and chlorophyll a fluorescence in rose plants. Environmental and Experimental Botany. 2008;64:65-74.

174. Shen H, Du H, Wang Z Huang B. Differential responses of nutrients to heat stress in warm season and cool-season turfgrasses. Horticulture Science. 2009;44:2009-2014.

175. Zhang X, Wang K, Ervin EH. Optimizing dosages of seaweed extractbased cytokinins and zeatin riboside for improving creeping bentgrass heat tolerance. Crop Science. 2010;50:316-320.

176. Taiz L, Zeiger E. Plant Physiology. 4th ed. USA: The Benjamin/Cummings Publishing Company; 2006.

177. Jiang Y, Huang B. Effects of calcium and antioxidant metabolism and water relations associated with heat tolerance in two cool-season grasses. Journal of Experimental Botany. 2001;355:341-349.

178. Fu J, Huang B. Effects of foliar application of nutrients on heat tolerance of creeping bentgrass. Journal of Plant nutrition. 2003;26:81-96.

179. Saidi Y, Finka A, Muriset M, et al. The heat shock response in moss plants is regulated by specific calcium-permeable channels in the plasma membrane. Plant Cell. 2009;21:2829-2843.

180. Fenner M, Thompson K. The Ecology of Seeds. London: Cambridge University Press; 2005;97:151-152.

181. Saeidnejad AH, Kafi M, Pessarakli M. Evaluation of cardinal temperatures and germination responses of four ecotypes of Bunium persicum under different thermal conditions. International Journal of Agriculture and Crop Sciences. 2012;17:1266-1271.

182. Batlla D, Grundy A, Dent KC, et al. A quantitative analysis of temperature-dependent dormancy changes in Polygonum aviculareseeds. Seed Science Research. 2009;49:428-438

183. Baskin CC, Baskin JM. Seeds: Ecology, Biogeography and Evolution of Dormancy and Germination. San Diego, USA: Academic Press; 1998.

184. Roberts EH. Temperature and seed germination. Symposium of Society of Experimental Biology. 1988;42:109-132.

185. Liu H, Baldwin CM, Luo H. Acid soil and aluminum tolerance in turfgrasses. In: M Pessarakli editor. Handbook of Turfgrass Management and Physiology. CRC Press, New York, USA: Taylor \& Francis Group; 2008. p. $373-386$

186. Liu H, Baldwin CM, Totten FW, McCarty LB. Foliar fertilization for turfgrasses. II. International Conference on turfgrass science and management for sports fields. Acta Horticulture. 2008;78(3):323-332.

187. Liu H, Menchyk N, Bethea F, et al. Nutrient management of golf course putting greens under stresses. In: M Pessarakli editor. Handbook of Plant and Crop Stress. 3rd ed. Florida: Taylor \& Francis Group; 2010;39:989-1018.

188. Busey P. Cultural management of weeds in turfgrass: A review. Crop Science. 2003;43:1899-1911.

189. Turgeon AJ, McCarty LB, Christians NE. Weed Control in Turf and Ornamentals. Upper Saddle River, New Jersey, USA: Prentice-Hall Inc; 2009.

190. Datnoff LE. Silicon in the life and performance of turfgrass. Applied Turfgrass Science. 2005. p.14-16. 